\title{
INTO THE APPLE STORE: THE BIRTH OF THE ROBERT T. SEELEY PROFESSORSHIP*
}

\author{
ERIC L. GRINBERG
}

\begin{abstract}
.
A casual visit to the Apple store brought major unexpected academic opportunities
\end{abstract}

\section{IN BRIEF.}

On a balmy June day I walked into the Apple Store with the intention to browse, and maybe talk, and not to buy. I came out with a brand new phone and multi-million dollar endowed professorship. But I'm getting ahead of myself.

\section{A GREAT FALL.}

As I waved my arms, illustrating a point in office hours, my cell phone went into free fall. Unlike previous falls from lap height, this time there were consequences: small screen cracks. I could live with them; many people do. (Indeed, my student's phone had a similar condition.) Or maybe I'll do a repair. It won't cost much. Or maybe I'll go to the Apple Store, in Chestnut Hill, our usual. I'll just talk and gather options. I won't buy anything. My wife and son mentioned going shopping for shoes in Dedham. There's an Apple Store there too. Maybe I'll come along.

\section{Into The Apple Store.}

On entering the Dedham Apple Store a friendly receptionist directed me to Rod. He'd help with the phone screen inquiry. Rod, based in another store, was on special assignment in Dedham. Clearly empathizing with the feelings of an injured cell phone, he compassionately and expertly helped me navigate options and choices. Then came costs and employer discounts. Normally I'd ask about Boston Children's Hospital, my wife's employer, a source of good past discounts (and maybe she would get me the phone...) But she was with our son at the shoe store. So I asked about a UMass Boston (UMB) discount. "Oh, you're at UMB? What do you do there?" Mathematics. "Mathematics? Hmm, we were thinking CS... Mathematics....we could do Mathematics..." At this point the conversation took a twist, and the world changed.

\section{An IDEA SURFACED.}

Rod is a member of a donor group, alumni brothers of an MIT fraternity. He had retired after a career in technology, but couldn't stand staying at home as a retiree. So he applied to the Apple Store. The acceptance rate for these prized jobs is lower than admission rates at top universities. But Rod made it, and was clearly enjoying the experience. At the same time, he was working with his donor group, aiming to support needs at institutions of higher learning. Somehow, I also sensed that honoring people with MIT links is of interest. (Rod reported that I spotted his MIT school ring; I don't remember that.) An idea surfaced.

For years we'd been talking at UMB about setting up a visiting professorship, something like Brown's Tamarkin, Yale's Gibbs or Michigan's Hildebrandt, each of which had benefited our colleagues. Years back, MIT's Pavel Etingof kindly gave me the book Recountings: Conversations with MIT Mathematicians [1]. In it, Isadore Singer lauds the Moore instructorship, and its role in MIT's meteoric rise. I lent the book with multiplicity, and it hasn't come back, but I do have a page scan of Singer's words. Repeatedly I cited his words in advocating the visiting professorship concept. Alas, cost was an obstacle.

\footnotetext{
*This is an expanded version of a Letter to the Editor, which will appear in the Notices of The American Mathematical Society. The title draws influence from the book Into the Magic Shop [4], by James Doty, a memoire about a boy, growing up in difficult circumstances, whose life was transformed by a visit to a village magic shop.
} 
The UMB campus is anchored to 1960s era infrastructure which, it turns out, was improperly built. Reconstruction was needed, from the (under)ground up, at great expense and with benefits not easily visible. Consequently, new initiatives were affected by financial friction. If only we had an external infusion of funds, we could work with that and make the Visiting Instructorship a reality. But where to look?

\section{Robert T. SeEley}

In the meantime, structural ideas about the Professorship developed. We could name it after Robert T. Seeley, perhaps the best known mathematician to teach at UMB. Seeley is known for his world-class research, e.g., as manifested in the Atiyah-Singer Index Theorem. In addition, he is known for his humanity. Bob left a tenured full-professorship to come to UMB, drawn to its mission as an affordable, accessible public university in an urban area. His advanced background notwithstanding, he volunteered to teach elementary courses. He generously offered Independent Study to advanced students. After retirement, he taught statistics in prisons. Thus, when Rod mentioned the donor group, the Seeley Visiting Professorship came to mind.

I also knew that Seeley did

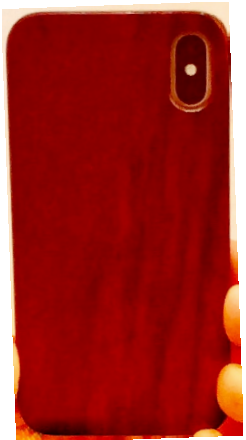

FIGURE 2

The phone that changed everything 1 his Ph.D with Alberto Calderon (MIT, 1959), so the Seeley Professorship would honor an MIT person, a plus for the donor group. I proposed the idea to Rod, and he seemed to find merit in it. At this point my Apple Store perspective gained clarity. I dispensed with all thoughts of discounts and bought the new phone. Then Rod and I exchanged addresses and agreed to talk again soon. I strolled to the parking lot, feeling renewed.

\section{A good SAlesman.}

I wrote to Rod next day, but didn't hear back for a long time. He's a good salesman, I thought in jest. I wrote again and heard back immediately. His daughter got married in Italy, he explained, and he spent the summer there. Now he was back, and online. We talked, and Rod took the idea to the donor group; things moved forward. During Rod's first UMB campus visit, I introduced him to Dennis Wortman, our most senior faculty member, a longtime colleague of Bob's, and an MIT Ph.D (with Ken Hoffman, 1972). This came just in time, before Dennis' retirement. At this stage I knew that I should turn things over to our University Advancement office; I began to work with Adam Wise and Ellen Fleming. They helped me navigate the part of the process that still involved me.

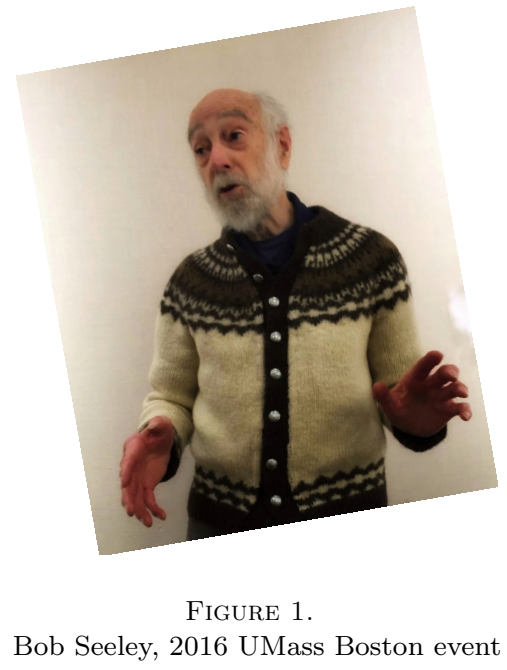

7. MOVING FORWARD.

There was a formal proposal to write. The question of money was unavoidable: "how much?" And administrative coordination would be needed, for resource matching. Adam and Ellen guided me through. Fortuitously, an AMS Notices Letter to the Editor appeared around the same time, extolling the virtues of Yale's Gibbs Instructorship 5. Then UMB Chancellor, Katherine Newman, had already worked with mathematics departments at a number of institutions. (As Forbes Professor at Princeton, she collaborated with the Mathematics department chair ("... Fermat's Last Theorem ... Andrew Wiles!") She was familiar with the Visiting Assistant Professor model, saw value in it, and viewed it as essentially unique to mathematics. Without hesitation, she found the campus resources needed to make the position a reality. The Board of Trustees of the University of Massachusetts system soon voted to affirm the endowed, Visiting Assistant Professorship, named for Robert T. Seeley. Not long after that, the first

\footnotetext{
${ }^{1}$ The title of the phone picture was inspired by my son's $4^{\text {th }}$ grade paper The Dog Who Changed Everything. The color of the phone case matches a family musical instrument.
} 
Seeley Professorship search was launched and completed successfully. The inaugural Seeley Visiting Assistant Professor is Alexander Moll (MIT Ph.D., with Alexei Borodin, 2016). His first year took place under the Covid cloud, alas, but we look forward to the second year, with on-campus, face to face interactions. And we look forward to sustained Seeley Professorship searches.

\section{The Story COntinues.}

Readers familiar with Nikolai Gogol's short story The Overcoat 22 may recall that the piece seems to come to a natural end, yet continues for a while. We are at a similar juncture here, though Grinberg is no Gogol. We could end the story now, or we can reflect on how this happened, and how it might be made to repeat. Did we have a plan? Or was this a Malcolm Gladwell Blink [3] moment? I hear ringing in my ears, emanating from the corridors of administration: "... you don't have a plan, ..., you don't have a plan. We didn't have a plan, though we did have the concept of the Seeley Professorship, which helped. And no plan could have included Rod, a warm, kind, generous and unique human being. We were also lucky to visit the Apple store in Dedham, on a day when Rod was on special assignment there, in the time before Covid. Could this have happened under remote modality? It's unthinkable.

UMass Boston

Email address: eric.grinberg@umb.edu
And then there's the parent company. Practicing promotional design without a license, I'm tempted to offer an ad line: The Apple Store: Bringing People Together. (Trite, but sincerely motivated.) This venue is more than a place to shop for a phone or laptop. The Store environment brought something wonderful, unexpected, and not electronic. Might Apple be interested in the Seeley Professorship? Approaching Rod wouldn't be fair. I know people who know people who work for Apple. Dare I ask?

\section{REFERENCES}

[1] J. Segel, ed, (2009). Recountings: Conversations with MIT Mathematicians. Wellesley MA: AK Peters Ltd.

[2] Gogol, Nikolai (1842). The Overcoat. en.wikipedia. org/wiki/The_Overcoat: Wikipedia.

[3] Gladwell, Malcolm (2005). Blink: The Power of Thinking Without Thinking. New York: Little, Brown \& Company.

[4] Doty., James R. (2016). Into The Magic Shop. New York: Avery.

[5] Seligman, G.B. and Beals, R. Additions to Browder Biography in December 2018 Notices, letter to the editor, Notices of the AMS (May 2019), vol. 66, no. 5 p 658.

\section{CREDITS}

Figure 1 is courtesy of Eric Grinberg.

Figure 2 is courtesy of the cell phone itself, taking a self-selfie, together with Eric Grinberg, for post processing. 